\title{
Security Dilemma dalam Ketegangan AS-Iran Pasca Serangan Kapal Tanker di Teluk Oman
}

\author{
Fenny Rizka Salsabila, Dina Yulianti \\ Program Studi Hubungan Internasional Universitas Padjadjaran \\ e-mail : fenny18001@mail.unpad.ac.id
}

\section{Abstract}

This article aims to examine the tensions that occurred between the US and Iran, especially after the explosion of two tankers in the GulfofOman on June 13, 2019. The US accused Iran of being the perpetrators of the attack and took various actions in response, including increasing its military posture in the region. This article answers questions about the root of this tension in terms of the security dilemma concept of Booth and Wheeler (2008). The research was conducted qualitatively using data from mass media, documents, and journal articles. The findings of this research are that the US and Iran each interpret the other party as an enemy but the response given is different. The US gave a confrontational response by bringing forward its economic and military strength, while Iran in addition to giving signals (words) of resistance also gave a signal of reassurance or guarantee that it was prioritizing diplomacy and cooperation.

Keywords: dilemma of interpretation, dilemma of response, Iran, security dilemma, United States

\section{Abstrak}

Artikel ini bertujuan untuk menelaah ketegangan yang terjadi antara AS dan Iran terutama setelah ledakan dua kapal tanker di Teluk Oman pada 13 Juni 2019. AS menuduh Iran sebagai pelaku serangan tersebut dan mengambil berbagai tindakan sebagai respon, antara lain meningkatkan postur militernya di kawasan. Artikel ini menjawab pertanyaan mengenai akar dari ketegangan ini ditinjau dari 
konsep security dilemma dari Booth dan Wheeler (2008). Riset dilakukan secara kualitatif dengan menggunakan data-data dari media massa, dokumen, artikel jurnal. Temuan dalam artikel ini adalah bahwa AS dan Iran masing-masing menginterpretasikan pihak lain sebagai musuh namun respon yang diberikan berbeda. AS memberikan respon konfrontatif dengan mengedepakan kekuatan ekonomi dan militer yang dimilikinya, sedangkan Iran di samping memberikan sinyal (kata-kata) perlawanan juga memberikan sinyal reassurance atau jaminan bahwa pihaknya mendepankan diplomasi dan kerjasama.

Kata Kunci: Amerika Serikat, dilema interpretasi, dilema respon, Iran, security dilemma

\section{Pendahuluan}

Pada Kamis 13 Juni 2019 terjadi insiden ledakan dua kapal tanker di Teluk Oman yang membuat hubungan AS dan Iran semakin memanas. Saat itu, kapal Kokuka Courageous yang berbendera Panama dan dioperasikan oleh perusahaan yang berbasis di Jepang; dan kapal Front Altair yang berbendera Marshall Island dan dioperasikan sebuah perusahaan Taiwan yang berbasis di Norwegia mengalami serangan di Teluk Oman. Kedua kapal tanker yang membawa nafta dan metanol itu mengalami serangan tepatnya di bagian barat laut Arab di ujung Selat Hormuz yang merupakan jalur pengiriman minyak di Timur Tengah. Teluk Oman menghubungkan Laut Arab dengan Selat Hormuz, selat yang merupakan pintu gerbang ke Teluk Persia. Meledaknya kapal tanker ini merupakan lanjutan dari konflik di perairan Arab sebelumnya, serangan terhadap empat kapal di perairan Uni Emirat Arab pada tanggal 12 Mei 2019. Dalam kedua serangan tersebut, AS menuduh Iran sebagai pelakunya. Sebaliknya, Iran menolak tuduhan itu dan menyatakan bahwa AS telah 'menunjukkan tingkah laku yang agresif' (BBC, 2019).

Sehari setelah serangan di Teluk Oman, Washington merilis video hitam-putih yang diklaimnya sebagai bukti bahwa militer Iran (IRGC) sedang memindahkan sebuah ranjau yang tidak meledak dari salah satu kapal sebagai upaya untuk menyembunyikan keterlibatan Tehran. Menlu Iran Javad Zarif membantah tuduhan ini dengan mengatakan bahwa pemerintah AS telah menuduh tanpa bukti faktual. Dalam tweet-nya, Zarif mengatakan bahwa ini adalah upaya 'sabotase diplomasi' dan menutupi aksi AS yang melakukan 'terorisme ekonomi' terhadap Iran. Sebelumnya, Zarif juga menulis di Twitter-nya kecurigaan atas timing kejadian ini. Saat terjadinya ledakan kapal Jepang itu, Perdana Menteri Jepang Shinzo Abe sedang berada di 
Teheran untuk melakukan upaya diplomatik peredaan ketegangan AS-Iran dan memperluas kerjasama ekonomi dengan Jepang-Iran. Zarif menulis, "Suspicious doesn't begin to describe what likely transpired" (Chappell, et al., 2019).

Saat terjadinya ledakan, baik AS maupun Iran telah mendapat sinyal permintaan tolong dari kedua kapal tanker. Kapal Angkatan Laut (AL) Iran lebih dulu sampai ke lokasi untuk menyelamatkan para kru kapal tanker. Sebanyak 23 kru kapal Front Altair diselamatkan oleh kapal AL Iran, sedangkan 21 kru kapal Jepang, Kokuka Courageous, diselamatkan kapal AL AS.

Sementara itu, penyebab serangan masih diperdebatkan. AS menuduh Iran menggunakan ranjau limpet. Namun kru kedua kapal memberikan kesaksian yang berbeda. Pihak kapal Frontline menyatakan bahwa kemungkinan kapal mereka ditembak oleh torpedo (Cunningham, et al. 2019). Sementara presiden perusahaan Kokuka Sangyo yang mengoperasikan kapal Kokuka Courageous, Yutaka Katada, menyatakan dia tidak percaya bahwa kapalnya diserang oleh ranjau atau torpedo. Alasannya, awak kapal melihat sesuatu terbang ke arah kapal yang kemudian menusuk lambung kapal. Selain itu bagian lambung kapal yang dihantam senjata jauh di atas permukaan air, sehingga kemungkinannya kecil itu disebabkan oleh ranjau atau torpedo (Chappell, et al., 2019).

Selain bertukar kata-kata saling kecam dan tuduh di antara pejabat kedua negara melalui media massa dan media sosial, di forum PBB pun terjadi ketegangan. Perwakilan AS untuk PBB dalam sidang Dewan Keamanan secara terbuka mengecam Iran sebagai pelaku serangan dan segera dibalas oleh perwakilan Iran. Menurut perwakilan Iran, "Iran categorically rejects the U.S. unfounded claim." Sementara itu, Sekretaris Jenderal PBB, António Guterres, menyerukan agar dilakukan penyelidikan independen. Menurutnya, "Sangat penting untuk mengetahui kebenaran dan sangat penting untuk diketahui pihak yang bertanggung jawab dan hal ini hanya bisa dilakukan melalui penyelidikan oleh pihak independen" (Wintour, 2019).

Berdasarkan pemaparan di atas, penulis mengajukan pertanyaan penelitian, apa penyebab ketegangan antara AS dan Iran khususnya dalam kasus ledakan kapal tanker di Teluk Oman? Beberapa penelitian sebelumnya telah membahas mengenai akar ketegangan kedua negara yang sebenarnya sudah berlangsung puluhan tahun. Barzegar (2010) menyimpulkan bahwa akar dari ketegangan itu adalah karena kedua negara memiliki peran penting di Timur Tengah, namun keduanya satu sama lain menganggap pihak lain bertentangan dengan kepentingan dan keamanannya. Sinkkonen (2019) menilai bahwa metode yang dipilih pemerintahan Trump terkait 
perjanjian nuklir (JCPOA) Iran dan langkah Trump dalam mempengaruhi Timur Tengah memberikan kontribusi besar pada peningkatan ketegangan yang terjadi di antara kedua negara. Vakil (dalam Gladstone\&Spacia, 2019) juga menilai ketegangan kedua negara disebabkan minimnya pemahaman pemerintahan Trump atas Iran, yang terlihat dari penggunakan bahasa penghinaan yang tidak akan berhasil untuk menekan Iran. Sementara itu, dalam penelitian ini, penulis mengimplementasikan konsep security dilemma yang dikemukakan oleh Booth and Wheeler (2008). Penelitian ini diharapkan dapat bermanfaat untuk menambah literasi terkait konflik AS-Iran dan menjadi bahan komparatif bagi penelitian semacamnya. Pemaparan selanjutnya akan dibagi menjadi beberapa bagian, yakni kronologi ketegangan AS-Iran sebelum dan sesudah meledaknya kapal tanker di Teluk Oman, penjelasan singkat mengenai konsep security dilemma, interpretasi dan respon AS terhadap Iran, interpretasi dan respon Iran terhadap AS, dan kesimpulan.

\section{Kronologi Ketegangan AS-Iran}

Relasi AS dan Iran memang selalu diwarnai dengan berbagai ketegangan. Jika kita kilas balik, berbagai ketegangan antara kedua negara dimulai sejak kemenangan revolusi Islam Iran tahun 1979. Pada saat itu Shah Iran yakni Mohammed Reza Pahlevi yang didukung oleh AS terpaksa meninggalkan negaranya akibat demonstrasi besarbesaran rakyat Iran yang memrotes berbagai kebijakan rezim monarkhi itu. Selama masa pemerintahan rezim Shah, hubungan Iran dan AS sangat dekat. Bagi Iran, beraliansi dengan AS memberikan perlindungan tingkat tinggi dari potensi serangan Soviet. Sebaliknya, bagi Washington, Iran memberi keuntungan karena Iran mau membuka wilayahnya bagi kehadiran AS dan bersedia membayar mahal keperluan militernya. Pada masa itu, Iran merupakan pengimpor senjata dari AS yang terbesar di kawasan. Besarnya anggaran militer Iran itu menyebabkan kemunduran ekonomi dan berbagai masalah sosial, sehingga akhirnya rakyat berdemo memprotes, antara lain dengan slogan-slogan anti-Amerika (McGlinchey, 2013).

Setelah tergulingnya Shah, dimulailah berbagai ketegangan antara Iran dan AS, terutama disebabkan karena upaya sabotase AS di awal-awal masa revolusi yang kemudian dibalas oleh para pemuda Iran dengan menyandera warga negara AS yang berada di Kedutan Besar AS di Teheran selama 444 hari (4 November 197920 Januari 1981). Akibat kasus penyanderaan itu, AS memutuskan hubungan diplomatik dengan Iran hingga hari ini. Selain itu, pada 4 November 1979, Presiden AS Jimmy Carter membekukan semua harta kekayaan Iran yang berada di wilayah 
hukum AS. Sejak saat itu hingga hari ini, ada berbagai jenis embargo yang diterapkan AS terhadap Iran, yaitu:

1. Sanksi keuangan/perbankan, yaitu larangan bagi lembaga yang berbasis di AS untuk melakukan transaksi keuangan dengan Iran, serta pemberlakukan aturan "Sanksi, Pertanggungjawaban, dan Divestasi Iran Komprehensif" (CISADA), dimana lembaga keuangan negara manapun yang berurusan dengan bank Iran akan dilarang melakukan transaksi di Amerika Serikat atau dengan mata uang dolar AS. Pada akhir 2011, AS mencegah importir minyak Iran melakukan pembayaran melalui bank sentral Iran, meskipun membebaskan sejumlah negara yang telah melakukan "pengurangan signifikan" dalam pembelian mereka. Selain itu, AS membatasi akses Iran ke mata uang asing sehingga dana dari importir minyak hanya dapat digunakan untuk perdagangan bilateral dengan negara pembeli atau untuk mengakses barang-barang kemanusiaan.

2. Sanksi ekspor minyak, yaitu melarang Iran mengekspor minyak dan melarang perusahaan asing memberikan jasa dan investasi di Iran di bidang minyak dan gas, penjualan peralatan yang digunakan dalam penyulingan minyak, dan partisipasi dalam kegiatan yang berkaitan dengan ekspor minyak, seperti pembuatan kapal, operasi pelabuhan, dan asuransi transportasi.

3. Sanksi perdagangan, yaitu AS melarang sebagian besar perusahaan AS melakukan perdagangan atau berinvestasi di Iran. Sanksi ini dimulai pada 1995 dan dilonggarkan pada tahun 2000. Lalu pemerintahan Obama membuat pengecualian terhadap penjualan peralatan telekomunikasi.

4. Pembekuan aset dan larangan bepergian, yaitu membekukan aset lusinan individu dan institusi Iran, termasuk bank, kontraktor pertahanan, dan Revolutionary Guard Corps (IRGC), serta melarang mereka berpergian ke luar negeri.

5. Sanksi pengembangan senjata, antara lain melalui Undang-Undang Nonproliferasi Senjata Iran-Irak (1992) yang memberikan sanksi kepada siapa pun yang membantu Teheran dalam pengembangan senjata atau perolehan "bahan kimia, biologi, nuklir, atau destabilisasi dan jenis senjata konvensional canggih" (Laub, 2015).

Pada November 2013, Iran dan 5 negara anggota tetap Dewan Keamanan PBB dan Jerman/Uni Eropa (yang disebut P5+1) menandatangani perjanjian interim yang disebut Joint Plan of Action yang memberikan kelonggaran pada sebagian 
sanksi, termasuk pencairan dana milik Iran sebesar 4,2 miliar Dollar AS yang semula dibekukan. Sebagai kompensasi, Iran berjanji membatasi pengayaan uranium dan mengizinkan pengawas internasional masuk ke kawasan sensitif di reaktor nuklirnya (Laub, 2015).

Pada 14 Juli 2015, setelah melalui berbagai negosiasi tingkat tinggi, AS bersama negara-negara anggota tetap Dewan Keamanan PBB dan Jerman/Uni Eropa akhirnya bersedia menandatangani Kesepakatan Nuklir JCPOA (Joint Comprehensive Plan of Actions). Di bawah kesepakatan ini, Iran berjanji membatasi program nuklirnya sampai pada level tertentu dan sebagai kompensasinya, AS (dan negara-negara Barat) bersedia menghentikan berbagai sanksi ekonomi terhadap Iran. Kesepakatan tersebut kemudian diadopsi menjadi Resolusi Dewan Keamanan 2231 tahun 2015. Meskipun demikian, JCPOA ini banyak ditentang politisi Partai Republik. Bahkan ketika Trump (kandidat Republikan) berkampanye, ia menjanjikan akan mengakhiri perjanjian tersebut jika menang dalam pemilu presiden. Janji itu ditepati Trump dengan mengumumkan mundurnya AS dari JCPOA pada 8 Mei 2018 dan mengancam akan menerapkan sanksi ekonomi yang lebih keras (Rahim, 2019).

Selanjutnya pada 7 Agustus 2018, pemerintahan Trump menerapkan embargo tahap pertama yang melarang semua perusahaan AS untuk berbisnis dengan Iran di bidang aeronautika, mobil, karpet, pistasio, kaviar, dan emas. Mulai November 2018, sanksi tahap kedua diterapkan berupa pembatasan dalam industri minyak dan perbankan. Akibat dari berbagai sanksi ini, perekonomian Iran terdampak sangat buruk. Manuver Trump berlanjut pada 8 April 2019 ketika ia mengumumkan bahwa militer Iran, Islamic Revolutionary Guard Corps (IRGC) sebagai organisasi teroris asing (Foreign Terrorist Organisation-FTO). Ini adalah pertama kalinya AS secara resmi menetapkan militer negara lain sebagai "kelompok teroris". Dengan pernyataaan bahwa IRGC adalah FTO, segala aliran keuangan dan perjalanan yang terkait dengan IRGC pun menjadi terlarang dan bisa dikenai sanksi oleh AS. Iran merespon manuver Trump dengan mendeklarasikan AS sebagai "negara sponsor terorisme" dan militer AS yang berada di kawasan Timur Tengah sebagai "kelompok teroris" (Aljazeera, 2019)

Selama bulan Mei 2019, terjadi beberapa ketegangan di antara kedua negara, antara lain pada 5 Mei 2018, Penasehat Keamanan Nasional AS, John Bolton mengumumkan bahwa AS tengah mengirim pesawat tempur pengebom ke Timur Tengah sebagai persiapan atas serangan Iran. Bolton mengatakan, "AS tidak ingin berperang dengan Iran tetapi AS bersiap sepenuhnya untuk merespon serangan apapun dari Iran." Tiga hari kemudian Iran merespon dengan pernyataan akan 
melanjutkan proses pengayaan uranium dan produksi air berat sebagai bagian dari penghentian komitmen Iran atas JCPOA karena perjanjian itu secara sepihak telah dilanggar AS.

Pada 12 Mei 2019, empat kapal diserang di perairan Uni Emirat Arab, yaitu dua kapal tanker minyak milik Saudi, Al-Marzoqah dan Amjad, kapal tanker Norwegia Andrea Victory, dan kapal tongkang Uni Emirat Arab. AS segera menuduh Iran pelaku serangan Iran yang segera dibantah oleh Iran. Pada hari yang sama, Pusat Komando Militera AS atau CENTCOM mengatakan bahwa sejumlah pesawat pengebom B-52 Stratofortress yang dikirim ke Timur Tengah untuk menekan Iran. Pengebom B-52 ini akan menjadi bagian dari pasukan militer tambahan yang dikirim AS ke Timur Tengah.

Selanjutnya, pada 14 Mei terjadi serangan drone terhadap dua stasiun pengeboran minyak Saudi di sebelah barat Riyadh. Pasukan Houthi Yaman menyatakan bahwa pihaknya yang mengirimkan drone tersebut, tetapi AS dan Saudi menuduh Iran ada di belakang serangan itu. Pada $19 \mathrm{Mei}$, sebuah roket menghantam Kedutaan Besar AS di Baghdad. Hingga kini belum diketahui pengirim roket tersebut, namun Trump menulis di Tweet-nya, "If Iran wants to fight, that will be the official end of Iran. Never threaten the United States again!"Menlu Iran membalas lewat akun Twitternya, menyatakan bahwa rakyat Iran telah berdiri tegak selama ribuan tahun sementara semua agresor tumbang. Zarif mengatakan kepada Trump, "Try respect-it works".

Di tengah ketegangan ini, Jepang berupaya menjadi penengah. Setelah Perdana Menteri Jepang Shinzo Abe menemui Trump pada 27 Mei, Trump mengeluarkan pernyataan, "Tidak menginginkan ada perubahan rezim di Iran." Sikap Trump yang seolah melunak ini kemungkinan untuk membujuk Iran. Namun, ketika pada 12 Juni Abe datang ke Iran, pemimpin tertinggi (Supreme Leader) Iran, Ayatullah Khamenei, menyatakan bahwa dia tidak akan membalas pesan dari Trump [yang dibawa Abe] karena "Trump tidak layak diajak berkomunikasi". Sehari kemudian, ketika Abe masih berada di Iran, tepatnya pada 13 Juni 2019, Kamis pagi, dunia dikejutkan oleh meledaknya dua buah kapal tanker minyak di Teluk Oman, kapal Kokuka Courageous milik perusahaan Jepang dan kapal Front Altair milik perusahaan Norwegia. AS segera menuduh Iran sebagai pelakunya dan pada 17 Juni, AS mengirimkan 1000 pasukan tambahan ke Timur Tengah (Aljazeera, 2019). 
Berikut ini peta yang menunjukkan lokasi serangan empat kapal di perairan UAE (12 Mei), dua kapal tanker di Laut Oman (13 Juni), dan posisi drone militer AS yang ditembak Iran (19 Juni).

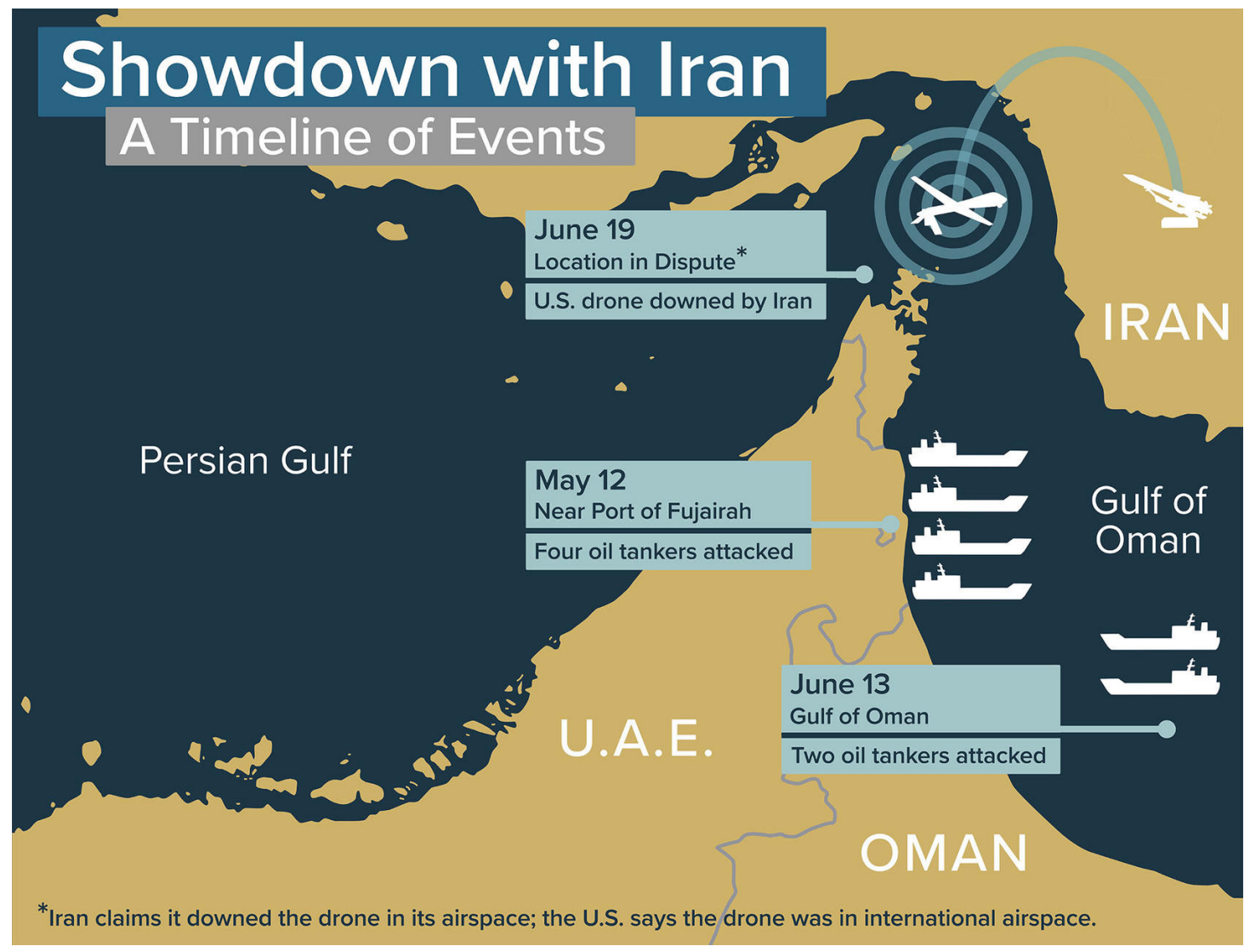

Sumber peta: usip.org (2019)

Selanjutnya, pada tanggal 20 Juni 2019, Iran menembak drone militer AS, RQ4A Global Hawk yang melintas di atas Selat Hormuz yang merupakan teritorial Iran. Dikutip dari pernyataan yang ditulis dalam akun twitter-nya (20 Juni 2019), Menteri Luar Negeri Iran, Javad Zarif, mengatakan bahwa AS telah melanggar batas wilayah Iran sehingga sudah patut Iran membela diri. Zarif menulis:

The US wages \#EkonomicTerrorism on Iran, has conducted covert action against us \& now encroaches on our territory. We don't seek war, but will zealously defend our skies, land \& waters. We'll takes this new aggression to \#UN \& show that the US is lying about international waters.

Melalui tweet-nya ini, Menlu Iran menegaskan bahwa posisi Iran bukan hendak mengobarkan perang, tetapi akan gigih mempertahankan langit, tanah, dan perairannya. Di hari yang sama, Presiden AS menulis dalam akun Twitter-nya bahwa 
Iran telah melakukan "kesalahan besar". AS pun mengirim pasukan tambahan, termasuk kapal induk dan dua pesawat pengebom B-52 keTimurTengah. Kementerian Pertahanan AS mengecam "serangan tidak beralasan di wilayah udara internasional" itu. Washington mengklaim drone mereka terbang sekitar 34 kilometer dari titik terdekat Iran ketika ditembak jatuh. Namun, Iran bersumpah akan membawa insiden ini ke Perserikatan Bangsa-Bangsa (PBB) untuk membuktikan bahwa AS "berbohong" (CNN Indonesia, 2019a).

Berikut ini peta versi lain yang menunjukkan lokasi serangan empat kapal di perairan UAE (12 Mei), dua kapal tanker di Laut Oman (13 Juni), dan posisi drone militer AS yang ditembak Iran (19 Juni).

\section{US drone shot down by Iran}

U.S. officials say an RQ-4A Global Hawk drone was shot down by Iran. The two countries have disputed the exact location.

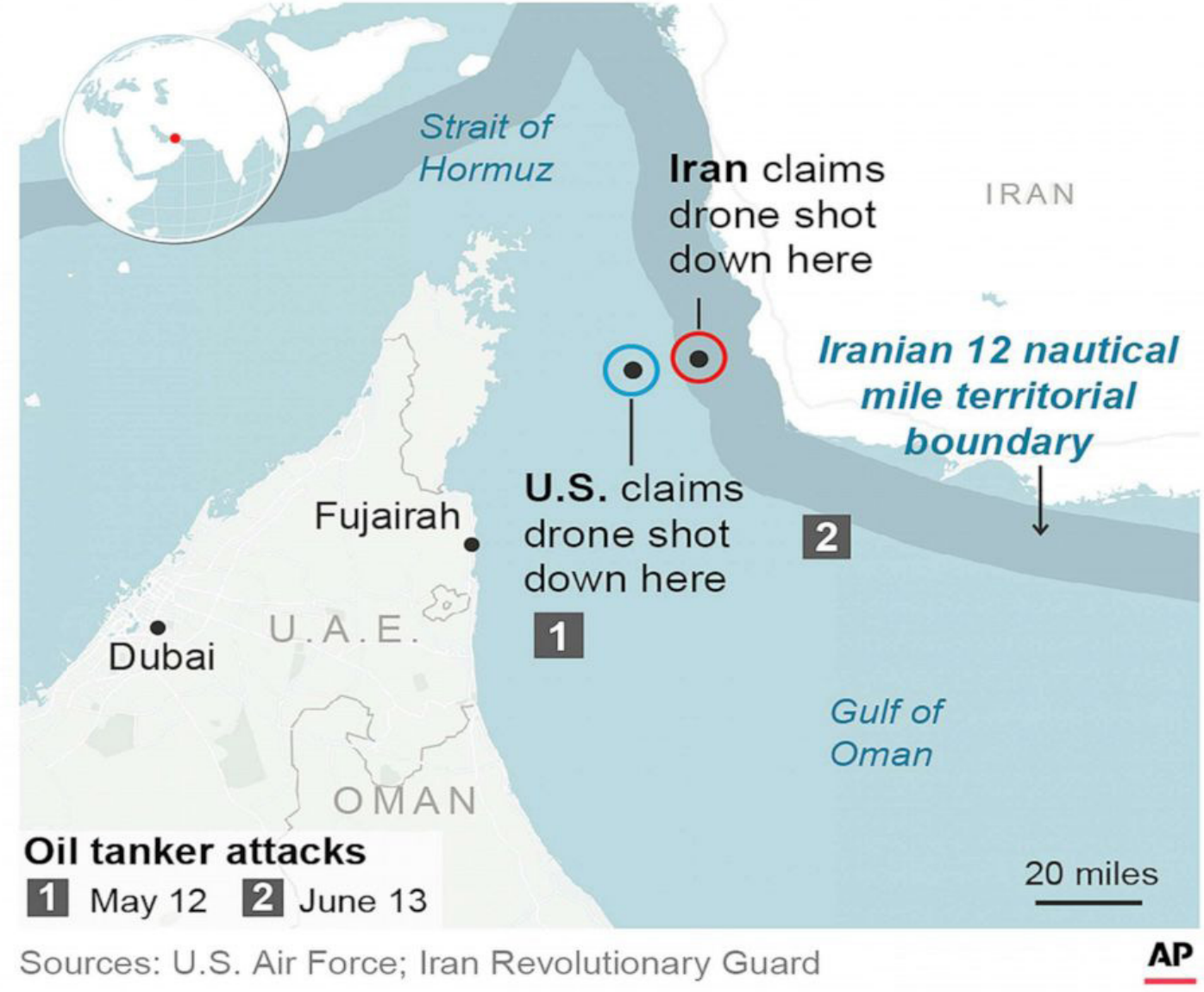


Dalam tweet tanggal 21 Juni, Presiden Trump menyatakan pihaknya telah siap melakukan serangan militer ke Iran, namun dibatalkan karena serangan akan membawa ratusan korban. Trump menulis, "Sanctions are biting \& more added last night." Dengan kata lain, alih-alih melakukan serangan militer, AS menambahkan sanksi ekonomi terhadap Iran. Keesokan harinya, Juru Bicara Kemenlu Iran, Abbas Mousavi, menjawab, "Kami tidak akan membiarkan pelanggaran terhadap perbatasan Iran. Iran akan dengan tegas menghadapi segala agresi atau ancaman oleh Amerika." Menlu Javad Zarif melalui Twitter-nya juga mengecam AS dan menyebut pemerintahan Trump "membenci diplomasi dan haus perang" (Aljazeera, 2019).

\section{Konsep Security Dilemma}

Konsep security dilemma adalah sebuah framework yang dapat menjelaskan pola interaksi antar negara dan menginterpretasikannya Security dilemma sering diasumsikan sebagai suatu kondisi dimana tindakan militeristik yang diambil oleh satu aktor untuk meningkatkan keamanan nasionalnya diartikan sebagai aksi agresif oleh aktor lain sehingga memprovokasi aktor lain tersebut untuk memberikan respon militer (Heywood, 2011). Konsep ini awalnya dikemukakan oleh Herz, Butterfield, dan Jervis pada tahun 1950-an. Herz mendefinisikan security dilemma sebegai sekelompok orang atau individu yang aktif secara politik dan sangat mengkahwatirkan bwah keamanan mereka akan diserang oleh kelompok lain dan kekahwatiran itu mendirikan mereka untuk mendapatkan power yang lebih besar untuk melindungi diri mereka. Dalam sistem internasional yang anarki, menurut Herz, negara dianggap tidak punya pilihan selain meningkatkan power-nya untuk melindungi diri. Dengan kata lain, security dilemma terkait dengan ketakutan sebuah negara atas niat negara lain dan karena itu negara berupaya mengakumulasi powernya (Herz, dalam Huwaidi, 2015).

Pada 2008, Booth dan Wheeler mengembangkan pemikiran mengenai security dilemma ini dalam buku mereka The Security Dilemma: Fear, Cooperation and Trust in World Politics. Mereka mengemukakan pemikiran bahwa security dilemma terdiri dari dua level strategic predicament atau kesulitan strategis, yaitu sebagai berikut.

1, Level pertama: dilema interpretasi, yaitu kesulitan yang dihadapi oleh para pengambil keputusan saat mereka menghadapi masalah-masalah yang mengancam keamanan naegara. Dilema ini terjadi ketika mereka harus mengambil keputusan dalam kondisi ketidakpastian mengenai motif, niat, 
dan kapabilitas pihak rival. Dengan kata lain, saat negara A melihat ada perkembangan militer yang dilakukan negara $B$, pengambil keputusan di negara $\mathrm{A}$ harus memutuskan apakah perkembangan itu untuk kepentingan pertahanan dan pembelaan diri negara $B$ atau untuk persiapan perang terhadap negara A.

2. Level kedua: dilema respons, yang akan muncul setelah dilema di level pertama sudah terlewati. Ketika pengambil keputusan di negara $A$ sudah menetapkan bahwa perkembangan militer di negara $B$ adalah untuk pertahanan atau untuk serangan, mereka harus memilih: apa respon yang tepat? Negara A memiliki beberapa pilihan, di antaranya: memberikan sinyal (melalui kata-kata dan perbuatan) bahwa mereka akan melakukan hal yang sama (misalnya, juga akan meningkatkan kapabilitas militer); atau mereka memberikan sinyal jaminan bahwa mereka tidak akan melakukan apapun yang mengancam keamanan bersama.

Jika dilema respon didasarkan pada kecurigaan atau kurangnya kepercayaan terhadap negara rival, lalu respon yang diberikan adalah aksi militer yang konfrontasional, akan terjadi kondisi yang disebut 'paradoks keamanan' (security paradox) dimana masing-masing negara sesungguhnya menginginkan keamanan dan untuk itu melakukan aksi-aksi yang kemudian memunculkan kecurigaan pihak rival namun akhirnya terjadi konflik atau perang yang justu menghilangkan keamanan itu sendiri (Booth dan Wheeler, 2008:4-5).

Dalam sebuah artikelnya, Wheeler dan Booth menulis bahwa kesalahan yang terjadi pada level pertama (interpretasi) terjadi akibat berbagai hal, mulai dari kesalahan membaca sinyal dalam sebuah konperensi diplomatik hingga kesalahan memahami informasi intelijen sehingga gagal dalam memprediksi aksi militer pihak rival. Hal ini tidak mengherankan karena memang sulit untuk memahami pemikiran orang dari bangsa lain, yang memiliki budaya yang berbeda, sehingga berakibat salah dalam menginterpretasikan motif dan niat negara rival. Apalagi, pemerintahan sebuah negara biasanya merahasiakan apa yang mereka katakan dan lakukan, serta sangat mungkin melakukan metode pengelabuan (deception) (Wheeler dan Booth, 2008).

Yang mendasari dinamika security dilemma adalah rasa takut (takut diserang, takut ditindas, takut kehilangan pengaruh ekonomi, dan lain sebagainya). Karena itu para pengambil keputusan seharusnya memiliki apa yang disebut security dilemma sensibility, yaitu niat dan kapasitas para pengambil keputusan untuk menangkap 
motif di balik aksi militer pihak rival dan memahami bahwa 'rasa takut' memiliki peran besar dalam perilaku sebuah negara; dan karena itu memahami bahwa apa yang dilakukan sebuah negara sangat mungkin menimbulkan ketakutan negara lain (Wheeler dan Booth, 2008).

\section{Interpretasi dan Respon AS Terhadap Iran}

Insiden meledaknya dua kapal tanker pada 13 Juni merupakan bagian dari rangkaian peristiwa sebelumnya, yaitu mundurnya AS dari JCPOA dan sanksi embargo ekonomi dengan alasan untuk menghentikan pengembangan nuklir Iran; lalu serangan terhadap empat kapal di perairan UAE; serangan drone Houthi terhadap stasiun pengeboran minyak di Riyadh, Arab Saudi; dan serangan roket atas Kedutaan Besar AS di Baghdad yang dipersepsi AS sebagai serangan Iran dengan menggunakan proxy. Serangan di Teluk Oman diikuti dengan masuknya drone militer AS, RQ-4A Global Hawk ke wilayah Iran dan direspon dengan serangan yang menghancurkan drone tersebut.

Laporan penelitian yang dilakukan Parlemen AS (Congressional Research Service), berjudul "US Iran Tensions and Implication for US Policy" menyatakan dengan jelas bahwa berbagai kejadian tersebut merupakan 'ancaman' bagi keamanan AS. Serangan terhadap Saudi pun, meski belum bisa dipastikan pelakunya adalah Iran juga dipandang sebagai ancaman bagi AS. AS selalu memandang bahwa Iran, sejak kemenangan revolusi tahun 1979 sebagai ancaman bagi AS dan sekutunya dengan alasan 'Iran membiayai faksi bersenjata di Timur Tengah' dan 'Iran berupaya membangun senjata nuklir dan membeli senjata konvensional serta membuat misil balistik' (Katzman, et al. 2019). Selain itu, militer Iran (IRGC) dianggap berpotensi mendorong sekutunya di Suriah, Lebanon, Irak, Yaman, Bahrain, dan Afghanistan untuk menyerang personel dan instalasi militer AS di kawasan. Katzman et.al (2019) juga mengutip laporan intelijen bahwa Iran memiliki "penemuan misil balistik terbesar di kawasan" dan "teknologi drone yang maju".

Selain itu, Iran memiliki lokasi yang sangat strategis serta cadangan minyak dan gas yang sangat besar. Iran mengontrol Selat Hormuz yang merupakan jalur lalu-lalang kapal tanker yang membawa minyak dari Timur Tengah ke Laut Hindia. Selain itu, Iran merupakan rute termudah dan terpendek bagi penyaluran minyak dan gas di Laut Kaspia menuju pasar Eropa dan Asia (Nuruzzaman, 2012). Posisi geostrategis Iran ini pun juga dipandang sebagai ancaman oleh AS (Katzman, et al. 
2019), terlebih karena Iran berkali-kali mengancam akan memblokir Selat Hormuz bila kepentingannya terancam.

Pemerintahan Trump secara eksplisit menyatakan bahwa pihaknya memandang negara-negara berdaulat di dunia ini berada dalam suasana kompetisi dan karena itu AS harus menggunakan semua kekuatan nasionalnya untuk melawan great power dan juga negara-negara kecil yang dikategorikannya sebagai rogue regime (rezim jahat) seperti Iran dan Korea Utara (Sinkkonen, 2019). Karena AS sejak 1979 mempersepsi Iran sebagai ancaman, interpretasi AS terhadap segala manuver yang dilakukan Iran pun bernilai negatif. Dengan kata lain, AS mencurigai Iran akan melakukan serangan terhadap AS dan sekutunya di kawasan (dalam laporan Katzman, et al. 2019, dua negara yang disebut sekutu AS adalah Arab Saudi dan Israel). Perlawanan yang dilakukan milisi Houthi terhadap Arab Saudi (yang menyerang Yaman sejak 2015) melahirkan interpretasi bahwa'Iran melalui proxy-nya memberikan ancaman kepada AS dan sekutunya.' Perlawanan Hizbullah dan Hamas (kedua milisi ini mendapatkan bantuan dari Iran) terhadap Israel diinterpretasi AS juga sebagai ancaman bagi AS dan sekutunya, yaitu Israel.

Karena pemerintah AS, khususnya Trump, memberikan interpretasi bahwa Iran adalah negara 'jahat', di antara respon yang diambil AS adalah mundur dari JCPOA. Keputusan ini mendapatkan dukungan dari dua sekutu dekat AS di kawasan, yaitu Arab Saudi dan Israel. Namun sebaliknya, negara-negara Eropa, serta Rusia dan China, tidak memberikan dukungan atas keputusan ini. Pemberlakukan embargo yang lebih ketat, setelah mundurnya AS dari JCPOA, juga merugikan negara-negara lain seperti India, China, dan Jepang yang sejak 2 Mei 2019 dilarang mengimpor minyak dari Iran. Di saat yang sama, Iran mengalami kerugikan karena kehilangan pendapatan utamanya (Sinkkonen, 2019).

Pasca insiden ledakan kapal tanker di Teluk Oman dan penembakan drone militer AS yang memasuki wilayah Iran, Trump sempat mengancam akan melakukan serangan militer, namun dibatalkan dan diganti dengan embargo. Trump memberikan respon berupa kata-kata yang keras dan penuh ancaman melalui media sosial (Twitter) maupun dalam berbagai pidatonya. Di saat yang sama, AS juga memberikan respon berupa tindakan yang memberi sinyal serangan militer, yaitu pengiriman pesawat pengebom B-52 Stratofortress ke Timur Tengah oleh AS dan dinyatakan jelas tujuannya, yaitu "untuk menekan Iran" serta penambahan 1000 pasukannya ke TimurTengah. 


\section{Interpretasi dan Respon Iran Terhadap AS}

Sejak 1979, yaitu kemenangan Revolusi Islam dan tergulingnya Shah, pemerintah AS berkali-kali melakukan upaya pengubahan rezim di Iran, antara lain melalui embargo ekonomi, tekanan politik, ancaman militer, maupun upaya diplomatik. Hal ini membuat Iran memandang AS sebagai musuh terbesar, sebagaimana tercermin dalam ucapan pemimpin Revolusi Iran, Ayatullah Khomeini, bahwa AS adalah 'Setan Besar'. Di antara manuver militer AS yang secara jelas menunjukkan upaya penggulingan pemerintahan Iran adalah dukungan kepada rezim Saddam (Irak) dalam menyerang Iran di tahun 1980-1988. Antara lain, pada tahun 1988 AS memberikan.memberikan informasi intelijen kepada Irak, yang didapat dari citra satelit tentang lokasi pasukan Iran meskipun mengetahui sepenuhnya bahwa tentara Irak akan menyerang dengan senjata kimia, termasuk dengan gas sarin yang mematikan (Harris dan Aid, 2013).

Embargo ekonomi juga memberikan ancaman terhadap Iran. Menurut data tahun 2015, Kementerian Keuangan AS memprediksi bahwa ekonomi Iran turun 15-20\% akibat sanksi dan kehilangan pendapatan minyak sebesar 160 miliar Dollar AS. Selain itu, ada lebih dari 100 miliar Dollar AS aset Iran di luar negeri yang dibekukan (Laub, 2015). Selain itu, pada tahun 2003, AS justru menyerang Irak dan menggulingkan Saddam, yang kemudian disusul seruan AS pada tahun 2004 untuk mengubah rezim di Iran dan Suriah. Selain itu, kepemilikan senjata nuklir oleh Israel juga memberikan ancaman bagi Iran, apalagi Israel juga berkali-kali memberikan ancaman serangan militer terhadap Iran. Semua hal ini memunculkan 'perasaan ketidakamanan yang serius' bagi Teheran (Nuruzzaman, 2012).

Di sisi lain, elit Iran meyakini bahwa sejarah, posisi geostrategis, sumber daya alam, dan sumber daya manusia yang dimiliki Iran adalah modal penting yang memberikan kemampuan bagi Iran untuk menjalankan peran penting dalam membentuk Timur Tengah dan. Asia Selatan. Mereka juga melalui sejarah panjang dimana negara-negara asing ikut campur dan mendominasi urusan dalam negeri mereka, seperti Inggris, Rusia, dan AS. Faktor-faktor ini memberi mereka persepsi bahwa mereka harus mandiri dan berdiri di atas dua kakinya sendiri untuk melindungi wilayahnya (Tabatabai, 2019). Persepsi Iran atas diri sendirinya akan mempengaruhi interpretasinya pada tindakan AS. Namun, meskipun Iran menginterpretasikan AS sebagai ancaman, kapabilitas Iran tidak memungkinkan untuk melakukan respon yang serupa dengan yang dilakukan 
AS. Sebagaimana terlihat di tabel berikut ini, perbandingan anggaran militer kedua negara dan jumlah persenjataan yang dimiliki sangat tidak berimbang.

Tabel Perbandingan Kekuatan Militer AS dan Iran

\begin{tabular}{|l|l|l|}
\hline & Amerika Serikat & Iran \\
\hline Jumlah Penduduk & 324.527 .000 & 78.192 .200 \\
\hline Bujet Militer & 610 miliar USD (3,1\% GDP) & $\begin{array}{l}14 \text { miliar USD }(2,5 \% \\
\text { GDP) }\end{array}$ \\
\hline Tentara & $\begin{array}{l}1.281 .900 \text { personel aktif } \\
811.000 \text { cadangan } \\
73.270 .043 \text { orang yang bisa } \\
\text { direkrut }\end{array}$ & $\begin{array}{l}550.000 \text { personel aktif } \\
350.000 \text { cadangan } \\
23.619 .215 \text { orang yang } \\
\text { bisa direkrut }\end{array}$ \\
\hline Angkatan Udara & $\begin{array}{l}457 \text { pesawat tempur } \\
2912 \text { pesawat serba guna } \\
512 \text { pesawat penyerang } \\
4889 \text { helikopter }\end{array}$ & $\begin{array}{l}130 \text { pesawat tempur } \\
73 \text { pesawat serba guna } \\
52 \text { pesawat penyerang } \\
324 \text { helikopter }\end{array}$ \\
\hline Angakatan Laut & $\begin{array}{l}20 \text { kapal pengangkut pesawat } \\
85 \text { kapal destroyer } \\
0 \text { frigate } \\
0\end{array}$ & $\begin{array}{l}0 \text { kapal pengangkut } \\
\text { pesawat } \\
0 \text { kapal destroyer } \\
71 \text { kapal selam }\end{array}$ \\
$\begin{array}{l}7 \text { frigate } \\
3 \text { corvette } \\
40 \text { kapal selam }\end{array}$ \\
\hline
\end{tabular}

Sumber: armedforce.eu

Menurut sejumlah laporan dari RAND (lembaga think tank terkemuka AS), para pemimpin Iran memandang bahwa doktrin militer Iran adalah defensif namun mereka meyakini bahwa negara mereka harus memiliki militer yang kuat, yang mampu menghalangi musuh dan meningkatkan resiko biaya bila musuh berniat 
menyerang. Dengan kata lain, postur militer Iran adalah didasarkan pada deterrence (Tabatabai, 2019).

Respon yang diberikan Iran atas ancaman keamanan yang dihadapinya adalah dengan mengadopsi strategi keamanan baru di Teluk Persia, yaitu dengan menjalin kerjasama yang lebih erat dengan negara-negara di kawasan. Antara lain, Presiden Ahmadinejad pada tahun 2007 hadir dalam pertemuan Dewan Kerjasama Teluk (GCC) di Doha. Ini adalah kunjungan pertama kalinya yang dilakukan Presiden Iran sejak GCC berdiri dan menunjukkan sinyal kuat bahwa Iran berusaha memulihkan hubungan strategis dengan negara-negara Arab dan berupaya untuk mengurangi dominasi AS di kawasan (Nuruzzaman, 2012). Pada era Presiden Rouhani juga dilakukan upaya pendekatan kepada negara-negara tetangga. Pada September 2019, Rouhani mengatakan bahwa Iran memulai inisiatif perdamain di Selat Hormuz (Hormuz Peace Initiative) dan "mengumumkan kepada dunia bahwa Iran menginginkan perdamaian yang langgeng di kawasan". Menurut Rouhani, solusi bagi ketegangan di kawasan haruslah datang dari negara-negara kawasan dan "mereka yang datang dari luar kawasan tidak pernah membawa perdamaian dan keamanan... AS telah berada di sini sejak 2001 namun tidak bisa menciptakan perdamaian dimana pun di kawasan ini" (Xin Hua, 2019)

Meledaknya dua kapal tanker di Laut Oman tersebut diinterpretasi Iran sebagai bentuk tekanan dari AS. Terbukti segera setelah serangan itu AS segera melemparkan tuduhan bahwa Iran adalah pelakunya. Iran merespon dengan mengungkapkan kecurigaan atas kejadian ini, yaitu karena sehari sebelum meledaknya dua kapal tanker (12 Juni 2019), Iran menerima kunjungan dari Perdana Menteri Shinzo Abe yang bermaksud meredakan ketegangan Iran-AS. Kepada Abe, Supreme Leader Iran, Ayatullah Khamenei mengatakan bahwa dia tidak akan membalas pesan dari Trump (yang dibawa Abe) karena "Trump tidak layak diajak berkomunikasi".

Menlu Iran Javad Zarif menulis di akun Twitternya:

Reported attacks on Japan-related tankers occurred while PM Shinzo Abe was meeting with Ayatollah Khamenei for extensive and friendly talks. Suspicious doesn't begin to describe what likely transpired this morning. Iran's proposed Regional Dialogue Forum is imperative (US News, 2019).

Juru bicara Kementerian Luar Negeri Iran, Abbas Mousavi, menyatakan bahwa Iran merasa prihatin atas terjadinya 'kejadian mencurigakan' terhadap dua kapal tanker yang terkait dengan Jepang. Menurutnya, "Kami melihat [kejadian] ini bertentangan dengan upaya di menurunkan ketegangan di kawasan" (Ratcliffe, et 
al, 2019). Pernyataan kecurigaan ini menunjukkan bahwa Iran justru menduga ada 'tangan' AS di balik serangan ini, terutama karena segera setelah itu Iran dituduh sebagai pelakunya.

Respon lain yang ditunjukkan Iran adalah memberikan bantuan kemanusiaan kepada para awak kapal kapal tanker yang meledak tersebut. Dalam insiden itu, Angkatan Laut Iran berhasil menyelamatkan 23 kru kapal Front Altair. Dalam rekaman wawancara yang disiarkan oleh televisi Iran, para kru menyatakan bahwa pelayanan Iran kepada mereka sangat baik dan segala sesuatunya dalam kondisi baik (Mehr News Agency, 2019).

Dari sisi motif, Iran tidak memiliki motif untuk menyerang kapal tanker Jepang itu, mengingat Iran memiliki hubungan baik dengan Jepang. Apalagi, ledakan itu terjadi di saat PM Jepang sedang berada di Teheran. Meskipun Jepang adalah sekutu AS, namun secara ekonomi Jepang dan Iran memiliki hubungan simbiosis mutualisme dimana kedua negara saling membutuhkan, yaitu Jepang membutuhkan minyak dari Iran, begitupun Iran membutuhkan pasar bagi produksi minyaknya.

Serangan Iran terhadap drone militer AS juga menunjukkan aspek fear, dimana Iran mengkhawatirkan adanya rencana serangan AS terhadap negaranya. Dengan demikian, tindakan Iran menembak drone milik AS seharusnya dipandang sebagai respon rasional dalam rangka melindungi keamanan negaranya sendiri, sebagaimana dikatakan Menlu Zarif, "Iran akan mempertahankan langit, tanah, dan perairannya." Aspek fear ini juga sejalan dengan tindakan Iran memperkuat militernya. Badan Inteligen Pertahanan AS mengatakan bahwa Iran memiliki sistem rudal yang paling canggih di Timur Tengah meskipun dunia internasional melalui berbagai embargo telah berupaya untuk menahan kemajuan Iran di bidang teknologi. Intelijen pertahanan AS juga mengakui bahwa Iran mengembangkan teknologi rudal 'demi mencegah serangan dari musuh di kawasan, terutama AS, Israel, dan Arab Saudi' (CNN Indonesia, 2019b).

Terkait tekanan yang diberikan AS terhadap proyek pengembangan nuklir Iran, Iran selalu menyatakan bahwa pihaknya memanfaatkan nuklir untuk tujuan damai. Iran telah menandatangani tiga perjanjian internasional terkait perlucutan senjata pembunuh massal, Treaty on the Non-Proliferation of Nuclear Weapons (NPT) pada tahun 1968, the Biological Weapons Convention pada 1996, dan Chemical Weapons Convention pada 1997. Sebagai penandatangan NPT, secara hukum Iran punya hak untuk mengembangkan nuklir untuk tujuan damai (memproduksi energi listrik, pengobatan, dan lain-lain). Namun sebaliknya, AS memandang bahwa program 
nuklir Iran adalah ancaman. Ini menunjukkan standar ganda AS, karena di saat yang sama, AS membiarkan Israel dan India tidak menandatangani NPT dan kedua negara itu memiliki senjata nuklir. Hal ini menunjukkan bahwa penolakan AS terhadap program nuklir Iran tidak didasari oleh hukum internasional melainkan didasari oleh tujuan politik (Prashad, 2019).

Penolakan AS atas hak legal Iran, termasuk mundurnya AS secara sepihak dari JCPOA membuat pemerintah Rouhani mengambil respon yang bersifat 'melawan'. Pada 2 Mei 2019 (setahun setelah AS mundur) Rouhani mengeluarkan pernyataan tegas bahwa jika para pihak dalam JCPOA, termasuk AS, tidak mau berunding dan memenuhi tuntutan Iran di bidang minyak dan perbankan, pihaknya akan melanjutkan pengayaan uranium. Hal ini merupakan titik balik dari sikap Rouhani sebelumnya yang terus mengupayakan negosiasi dengan Barat meskipun mendapat penentangan dari kelompok konservatif di dalam negeri yang cenderung tidak mempercayai Barat (Tabatabai, 2019). Kemudian pada 7 Juli 2019 Iran kembali mengeluarkan ancaman akan memulai kembali proses pengayaan uranium 'pada tingkat apa pun' dengan 'jumlah yang tak terbatas'. Langkah ini diambil Iran setelah AS dan negara penanda tangan JCPOA lainnya tidak juga memenuhi janji mereka menghentikan embargo atas Iran. Sebelumnya, Iran sudah menghentikan pengayaan uraniumnya sesuai kesepakatan JCPOA dengan imbalan bahwa sanksi akan dicabut. Namun di saat yang sama, Iran memberikan sinyal reassurance (jaminan) bahwa Tehran masih mendukung negosiasi dengan P4+1. Presiden Rouhani dalam pidatonya tanggal 5 November 2019 mengatakan,

In the next two months, we still have a chance for negotiations. We will negotiate and talk with each other, and if we find the right solution, and the solution is in lifting of the sanctions, and that we will be able to sell our oil easily, we will be able to use our money in banks easily, and other issues that they have imposed sanctions on, such as metals and insurance, and if they lift sanctions fully, we will also return to the previous conditions fully (dalam Katzman et, al. 2019).

Dalam kasus nuklir Iran, AS tidak mempertimbangkan doktrin-doktrin relijius Iran yang menolak adanya senjata pembunuh massal. Sebagaimana dikatakan Ayatullah Khamenei, Supreme Leader Iran, "Building and stockpiling nuclear bombs is wrong and using it is haram" (Reuters, 2019). Kesalahan interpretasi ini sudah disebutkan oleh Booth dan Wheeler, yaitu bahwa kesalahan dalam memahami pemikiran orang dari bangsa lain, yang memiliki budaya yang berbeda, dapat berakibat salah dalam menginterpretasikan motif dan niat negara rival. 
Di samping menyampaikan narasi yang berusaha menurunkan ketegangan (misalnya bahwa'Iran menginginkan perdamaian di kawasan'), Iran juga memberikan perlawanan terhadap pernyataan-pernyataan yang bersifat menyerang yang disampaikan AS. Misalnya, ketika Trump mengatakan bahwa Iran telah melakukan 'kesalahan besar' dan mengancam untuk membalas tindakan Iran dengan serangan militer, Iran merespon dengan ancaman 'akan membinasakan kapal perang AS dengan senjata rahasia' dan mengatakan bahwa tindakan AS adalah 'suatu kebodohan'. Iran pun menyatakan akan mengadukan 'kebohongan' AS (dalam kasus serangan drone) ke PBB. Dalam menanggapi insiden ini, PBB menyatakan keprihatinannya dan menekankan perlu adanya penyelidikan terkait insiden ini lebih lanjut.

\section{Kesimpulan}

Sepanjang tahun 2019 terjadi beberapa insiden yang meningkatkan ketegangan hubungan AS dan Iran sehingga berdampak pada semakin memanasnya kondisi geopolitik di TimurTengah. Di antara insiden itu adalah meledaknya dua kapal tanker yakni kapal Front Altair milik Norwegia dan Kokuka Courageous milik Jepang di Teluk Oman. Selanjutnya, Iran menembak drone militer AS dan disusul dengan berbagai ancaman militer dari AS, disertai pengiriman tambahan pasukan AS ke Timur Tengah.

Dengan mengimplementasikan konsep security dilemma yang dikemukakan Booth and Wheeler (2008), dilema interpretasi dan dilema respon yang dihadapi kedua negara satu sama lain dianalisis. AS menginterpretasi Iran sebagai ancaman bagi AS dan sekutunya. Di antara faktor yang dijadikan bukti ancaman itu adalah program nuklir Iran, serangan atas kapal tanker di Laut Oman, dan serangan terhadap drone militer AS. Sebagai respon, AS melakukan kebijakan konfrontatif, yaitu pengetatan embargo ekonomi dan memberikan berbagai pernyataan keras berupa tuduhan (bahwa Iran pelaku serangan kapal tanker) dan ancaman (serangan militer). AS juga melakukan manuver berupa pengiriman pesawat pengebom B-52 Stratofortress ke Timur Tengah yang diklaimnya sebagai upaya untuk menekan Iran. Selain itu AS juga menambah personel tentaranya di Timur Tengah.

Sementara itu, Iran juga menginterpretasikan AS sebagai ancaman dengan alasan bahwa sejak 1979 AS telah melakukan berbagai upaya untuk menggulingkan pemerintahan Islam Iran, antara lain dengan mendukung rezim Saddam (Irak) dalam memerangi Iran, menerapkan embargo ekonomi, dan melarang Iran mengembangkan proyek nuklir damainya. Namun postur dan kapabilitas militer 
Iran jauh di bawah AS sehingga Iran memberikan respon yang defensif, yaitu tidak menyerang tetapi mempersiapkan diri terhadap kemungkinan serangan. Hal ini sejalan dengan doktrin militer Iran yang defensif dan deterrence. Di saat yang sama, Iran juga memberikan sinyal reassurance atau jaminan bahwa pihaknya mendepankan diplomasi dan kerjasama.

\section{Daftar Pustaka}

Aljazeera. (2019). US-Iran standoff: A timeline of key events. [online]. Dalam: https://www.aljazeera.com/news/2019/06/iran-standoff-timeline-keyevents-190622063937627.html [Diakses 15 Desember 2019]

Associated Press. (2019). Peta, dimuat dalam: https://abcnews.go.com/ Politics/president-trump-ordered-military-strike-iran-reversed-sources/ story?id=63853570 [Diakses 15 Desember 2019]

Armedforces.eu. Military power of USA \& Iran. [online]. Dalam: https://armedforces. eu/compare/country_USA_vs_Iran [Diakses 15 Desember 2019]

Barzegar, K. (2010). Roles at Odds: The Roots of Increased Iran-U.S. Tension in the Post-9/11 Middle East. Iranian Review of Foreign Affairs, 1 (3), 85-114.

BBC. (2019). Trump Menuduh Iran Melakukan Serangan Dua Kapal Minyak di Teluk Oman. Indonesia. [online]. Dalam: https://www.bbc.com/indonesia/ dunia-48608784 [Diakses 15 Desember 2019]

Booth dan Wheeler. (2008). The Security Dilemma: Fear, Cooperation and Trust in World Politics. Basingstoke: Palgrave Macmillan.

Chappell, B., Kenyon, P., Neuman, S. (2019). Iran Denies U.S. Claim That It Attacked Tankers In Gulf Of Oman. NPR. [online]. Dalam: https://www.npr. org/2019/06/14/732619332/iran-denies-u-s-claim-that-it-attacked-tankers-ingulf-of-oman [Diakses 16 Desember 2019]

CNN Indonesia. (2019a). Trump Kecam Iran Usai Tembak Drone AS. [online]. Dalam: https://www.cnnindonesia.com/internasional/20190621104505-134-405188/ trump-kecam-iran-usai-tembak-drone-as [Diakses 12 Desember 2019]

CNN Indonesia. (2019b). AS Sebut Rudal Iran Paling Canggih di Timur Tengah. [Online]. Dalam: https://www.cnnindonesia.com/ 
internasional/20191120104223-134-449893/as-sebut-rudal-iran-palingcanggih-di-timur-tengah [Diakses 13 Desember 2019]

Cunningham, E., Gearan, A., Morello, C. (2019). U.S. blames Iran for attack on oil tankers, releases video purporting to show Iranians removing mine. Washington Post. [online]. Dalam: https://www.washingtonpost.com/world/oil-tankersattacked-in-gulf-of-oman-us-navy-says/2019/06/13/d59b784c-8db0-11 e9b162-8f6f41ec3c04_story.html [Diakses 13 Desember 2019]

Harris, S. dan Aid, N.M. (2013). Exclusive: CIA Files Prove America Helped Saddam as He Gassed Iran. Foreign Policy. [online]. Dalam: https://foreignpolicy. com/2013/08/26/exclusive-cia-files-prove-america-helped-saddam-as-hegassed-iran/ [Diakses 26 Desember 2019]

Heywood, A. (2011). Global Politics. New York: Palgrave Macmillan

Huwaidi, M.B. (2015). The Security Dilemma in Saudi-Iranian Relations. Review of History and Political Science Vol. 3, No. 2, pp. 69-79 DOI: 10.15640/rhps.v3n2a8

Katzman, K., Mcinnis, K.J., dan Thomas, C. (2019). US Iran Tensions and Implication for US Policy, (Congressional Research Service Paper) https://fas.org/sgp/crs/ mideast/R45795.pdf [Diakses 26 Desember 2019]

Laub, Z. (2015). International Sanctions on Iran. Council on Foreign Relations. [online]. Dalam: https://www.cfr.org/backgrounder/international-sanctions-iran [Diakses 26 Desember 2019].

McGlinchey, S. (2013). How the Shah Entangled America. National Interest. [online]. Dalam: https://nationalinterest.org/commentary/how-the-shah-entangledamerica-8821 [Diakses 15 Desember 2019]

Mehr News Agency. (2019). VIDEO: Rescued crew of oil tankers in Sea of Oman thank Iran. [online]. Dalam: https://en.mehrnews.com/news/146415/VIDEO-Rescuedcrew-of-oil-tankers-in-Sea-of-Oman-thank-Iran [Diakses 26 Desember 2019]

Nuruzzaman, M. (2012). Conflicts between Iran and the Gulf Arab States: An Economic Evaluation. Gulf University for Science and Technology Kuwait. [Online]. Dalam: https://www.researchgate.net/publication/271669914_Conflicts_between_ Iran_and_the_Gulf_Arab_States_An_Economic_Evaluation_[Diakses 16 Desember 2019] 
Prashad, V. (2019). Iran has lawful right to nuclear energy program. Asia Times. [online]. Dalam: https://www.asiatimes.com/2019/07/opinion/iran-has-lawfulright-to-nuclear-energy-program/ [Diakses 26 Desember 2019]

Rahim, M. H. (2019). Post JCPOA. Jurnal ICMES, 3(1), 27-52. https://doi.org/10.35748/ jurnalicmes.v3i1.42

Ratcliffe, V. Dipaola, A. Stanley, B. (2019). U.S. Sees State Actor Behind Oil Tanker Attacks in Gulf Region. Bloomberg. [online]. Dalam: https://www.bloomberg. com/news/articles/2019-06-13/oil-tanker-on-fire-in-sea-of-oman-u-k-bodystarts-probe [Diakses 16 Desember 2019]

Republika. (2019). Mulai Hari ini, Iran Tingkatkan Pengayaan Uranium. [online] Dalam: https://internasional.republika.co.id/berita/pu9ps8409/mulai-hari-ini-irantingkatkan-pengayaan-uranium [Diakses 26 Desember 2019]

Reuters. (2019). Iran's Khamenei says building, using nuclear bomb is forbidden under its religion: TV [online]. Dalam: https://www.reuters.com/article/us-iran-nuclearkhamenei/irans-khamenei-says-building-using-nuclear-bomb-is-forbiddenunder-its-religion-tv-idUSKBN1WO15H [Diakses 26 Desember 2019]

Sharafeddin, B. 2019. Iranian leader tells Japan's Abe Trump 'not worthy' of a reply to message. Reuters. [online]. Dalam: https://www.reuters.com/article/us-iranjapan-usa-khamenei/iranian-leader-tells-japans-abe-trump-not-worthy-of-areply-to-message-idUSKCN1TE14V [Diakses 26 Desember 2019]

Sikkonen, V. 2019. The United States-Iran Standoff: Recent tensions are symptomatic of President Trump's broader foreign-policy approach. Finnish Institute of International Affairs. [online]. Dalam: https://www.fiia.fi/en/publication/theunited-states-iran-standoff [Diakses 26 Desember 2019]

Specia, M. dan Gladstone, R. (2019). The Tension Between America and Iran, Explained. New York Times. [online]. Dalam: https://www.nytimes.com/2019/05/16/world/ middleeast/iran-tensions-explainer.html [Diakses 26 Desember 2019]

Tabatabai, A.M. (2019) Iran's National Security Debate Implications For Future US Iran Negotiations. RAND Corporations Paper. [online]. Dalam: https://www.rand.org/ pubs/perspectives/PE344.html [Diakses 16 Desember 2019]

Usip.org. (2019). Peta, dimuat dalam: https://www.usip.org/publications/2019/06/ origins-and-future-iran-crisis [Diakses 15 Desember 2019] 
US News . (2019). Iran's Zarif Calls Oil Tanker Incidents 'Suspicious', Wants Regional Talks. [Online]. Dalam https://www.usnews.com/news/world/articles/2019-06-13/ irans-zarif-calls-oil-tanker-incidents-suspicious-wants-regional-talks [Diakses 18 Desember 2019]

Wheeler, N. dan Booth, K. (2008). Rethinking the Security Dilemma. [online]. Dalam: https://www.researchgate.net/publication/37146990_Rethinking_the_ Security_Dilemma [Diakses 26 Desember 2019]

Wintour, P. 2019. UK joins US in accusing Iran of tanker attacks as crew held. The Guardian. https://www.theguardian.com/world/2019/jun/14/us-accuses-iranof-detaining-crew-after-oil-tanker-attack [Diakses 26 Desember 2019]

Xin Hua. 2019. Iran says "Hormuz Peace Initiative" seeks durable peace in region. [online]. Dalam: http://www.xinhuanet.com/english/2019-09/23/c_138415136. htm [Diakses 26 Desember 2019] 